\title{
PENGARUH VIDEO ADVERTISING DAN SOSIAL MEDIA KONTEN MELALUI BRAND AWARENESS TERHADAP MINAT BELI PADA APLIKASI GOFOOD DI KOTA MAKASSAR
}

\author{
Mashur Razak ${ }^{1}$, Muhammad Hidayat ${ }^{2}$, Muhammad Hidayatullah Rahman ${ }^{3}$ \\ STMIK Handayani Makassar ${ }^{1}$ STIE Nobel Indonesia Makassar ${ }^{2,3}$ \\ Email mashur_razak@yahoo.co.id \\ muhammadhidayatullahr@gmail.com ${ }^{3}$
}

\begin{abstract}
Abstrak
Tujuan dari penelitian ini adalah untuk menganalisis pengaruh langsung maupun tidak langsung antara video advertising dan sosial media konten melalui brand awareness terhadap minat beli pada aplikasi GoFood di Kota Makassar.Dalam penelitian ini peneliti menggunakan jenis penelitian deskriptif dengan pendekatan kuantitatif. Populasi dalam penelitian ini adalah pengguna aplikasi GoFood di Kota Makassar sebanyak 95 orang, penentuan ukuran sampel berdasarkan rumus Hair dimana besaran sampel adalah 5-10 kali dari jumlah indikator. Penelitian ini menggunakan 19 indikator di kali 5 sehingga jumlah sampel menjadi 95. Teknik pengambilan sampel menggunakan random sampling dengan pendekatan purposive sampling. Teknik analisis data dalam penelitian ini adalah Partial Least Square menggunakan aplikasi Smart PLS.Hasil penelitian ini menunjukkan bahwa (1) Video advertising berpengaruh terhadap minat beli (2) Sosial media konten tidak berpengaruh terhadap minat beli (3) Video advertising melalui brand awareness berpengaruh terhadap minat beli (4) Sosial media konten melalui brand awareness berpengaruh terhadap minat beli (5) Brand awareness berpengaruh terhadap minat beli pada aplikasi GoFood di Kota Makassar.
\end{abstract}

\begin{abstract}
The purpose of this study is to analyze the direct and indirect effects of video advertising and social media content through brand awareness toward purchase interest in the GoFood application in Makassar City. In this study, the researchers used descriptive study with a quantitative approach. The population in this study were 95 users of the GoFood application in Makassar City, determining the sample based on the Hair formula where the sample size was 5-10 times the number of indicators. This study used 19 indicators at times 5 so that the number of samples becomes 95. The sampling technique used random sampling with a purposive sampling approach. The data analysis technique in this study was Partial Least Square using the Smart PLS application. The results of this study indicate that (1) Video advertising has an effect toward purchase intention (2) Social media content has no effect toward purchase intention (3) Video advertising through brand awareness has an effect toward purchase interest (4) Social media content through brand awareness has an effect toward purchase interest (5) Brand awareness affects purchase interest in the GoFood application in Makassar City.
\end{abstract}

Keywords: Video Advertising, Social Media Content, Brand Awareness, Purchase Interest

\section{PENDAHULUAN}

Dari data Badan Pusat Statitik (BPS) tentang industri makanan dan minuman di Indonesia pada tahun 2020 menunjukkan perkembangan yang cukup pesat Industri makanan dan minuman periode April-Juni 2020, tumbuh 0,22 persen secara tahunan (y-o-y). Dan Data Badan Ekonomi Kreatif menunjukkan kontribusi sektor kuliner terhadap unit usaha ekonomi kreatif telah mencapai $41,69 \%$, tertinggi diantara 15 subsektor lainnya di tahun 2020 . Pada industri makanan dan minuman bidang usaha yang berkembang saat ini adalah bidang usaha seperti café dan restaurant (Indraswari \& Kusuma, 2018).

Peningkatan pada industry makanan dan minuman yang cukup fenomenal ini terjadi akibat adanya dukungan Pemerintah dalam memberikan kemudahan kepada para pelaku usaha 


\section{AkMen \\ Volume 18 Nomor 1 April 2021 \\ Hal. 84 - 97 \\ e-ISSN : 2621-4377 \& p-ISSN : 1829-8524 \\ Hbmepage: https//e-jurnal.stiendbel-indonesiaacid/indexphp/akmen}

dalam membuka bisnis kuliner. Namun demikian, perkembangan dan peningkatan tersebut menciptakan efek baru dalam lingkungan Indusri yaitu tumbuhnya peningkatan persaingan diantara pelaku usaha. Upaya - upaya untuk meningkatkan competitiveness saat ini juga melibatkan kemampuan pemanfaatan tekhnologi yang juga terus berkembang dengan pesat yang tak dapat dipungkiri semakin meningkatkan iklim usaha yang kompetitif sejalan dengan perubahan lingkungan usaha yang berubah dengan cepat (Azhar \& Arifin, 2011);(MeadowsKlue, 2008) Penggunaan tekhnologi menjadi semakin massif saat ini beriringan dengan bagkitnya revolusi industry 4.0 yang menuntut pada semua usaha untuk mampu memanfaatkan tekhnologi (Smuts \& Merwe, 2020);Sehingga mereka dapat terus eksis dan memiliki competitiveness (Bal \& Erkan, 2019) untuk hal tersebut maka dari sisi marketing pun harus mampu mengambil peran dalam lingkungan usaha yang kompetitif dan menuntut penyesiuaian terhadap strategi marketing yang lebih adaptif yang dapat dikembangkan oleh perusahaan (Maria et al., 2017).

Dukungan pemerintah serta perkembangan tekhnologi menciptakan berbagai kesempatan di bidang lain layaknya dalam konsep economic driver effect yang ditimbulkan dari semakin maraknya bisnis makanan dan minuman adalah berkembangnya layanan pesan antar dengan menggunakan kemajuan teknologi melalui aplikasi online services di Indonesia. Perkembangan transportasi online dewasa ini sudah semakin pesat, setelah rilis pada tahun 2015 kehadiran transportasi online mendapat sambutan dan tangapan publik yang sangat positif salah satunya adalah kehadiran transportasi online yang dimanfaatkan oleh para pelaku bisnis kuliner untuk mendukung usaha mereka, transportasi on line merupakan pilihan bagi orang-orang yang sibuk dengan segala aktivitas namun membutuhkan hal-hal praktis untuk memenuhi kebutuhan dasarnya kini kehadirannya sudah menjadi bagian yang sangat penting bagi masyarakat..

Transportasi on line kini menjadi alat bagi perusahaan untuk membantu melayani konsumen sehingga konsumen tidak mengalami hambatan jarak untuk berinteraksi dengan perusahaan begitu pula sebaliknya Selain menggunakan transportasi online untuk menarik konsumen dengan layanan delivery order, aplikasi on line yang dibangun oleh perusahaan juga merupakan bentuk respon dari para pelaku bisnis kuliner dari perkembangan teknologi sehingga selain aplikasi delivery order saat ini banyak perusahaan telah memanfaatkan teknologi dengan lebih luas salah satunya adalah pengembangan konsep e-markering . (Zamrudi \& Wicaksono, 2018).

Salah satu layanan pesan on line di Indonesia adalah goo food, berdasarkan riset yang dilakukan oleh Nielsen (2019) Singapura, berjudul "Understanding Indonesia's Online Food Delivery Market" mengungkapkan 84\% masyarakat yang menggunakan lebih dari satu aplikasi pesan-antar makanan menganggap GoFood menawarkan layanan pesan-antar makanan terbaik di Indonesia, jauh lebih tinggi dibandingkan dengan rata-rata industri (39\%). Capaian goFood tersebut tidak terlepas dari Brand yang telah dibangun sebagai salah satu unit usaha dibawah Gojek tentunya Gofood memiliki keunggulan sebagai brand leader dan sebagai pioneer dalam transportasi on line di Indonesia sehingga brand awareness yang diharapkan terbentuk pada masyarakat menjadi salah satu kekuatan Gojek.

Brand awareness (Kesadaran merek) adalah kemampuan bagi calon pembeli dalam mengenali dan mengingat suatu merek tertentu (Tjiptono, 2011). Pembelian tidak hanya terjadi begitu saja, tetapi pembelian akan melalui serangkaian proses tertentu. Proses tersebut dari mengidentifikasi kebutuhan, mencari informasi, mengevaluasi berbagai pilihan, hingga membuat keputusan pembelian (K. Kotler, 2011). Tentunya dalam proses pencarian informasi, konsumen perlu peka terhadap berbagai informasi terkait merek yang akan dibeli di lingkungan sekitarnya. Kepekaan konsumen terhadap merek yang akan digunakan erat kaitannya dengan brand awareness, hal ini seperti yang diungkap oleh para peneliti seperti (Chi, 2009); (Gusti Noorlitaria, Pangestu, Fitriansyah, Surapati, \& Mahsyar, 2020); (Akhtar, Ashraf, \& Latif, 2016);(Shahid, Hussain, \& Zafar, 2017) yang menyatakan bahwa brand awareness berpengaruh terhadap purchase intention, dengan demikian maka menjadi penting bagi perusahaan untuk 


\section{AkMen \\ Volume 18 Nomor 1 April 2021 \\ Hal. 84 - 97 \\ e-ISSN : 2621-4377 \& p-ISSN : 1829-8524 \\ Hbmepage: https//e-jurnal.stiendbel-indonesiaacid/indexphp/akmen}

meningkatkan brand awareness (Karam, 2015). Brand awareness juga akan sangat berpengaruh terhadap market outcome (Huang \& Sarigöllü, 2012) Pengenalan merek oleh konsumen akan menjadi preferensi yang kuat bagi konsumen sehingga mereka cenderung mengingat brand yang dikenalnya ketika memutuskan pembelian terhadap barang dan jasa

Dengan mengingat atau mengenal produk yang menjadi pilihan utamanya dalam membeli, maka intensitas pembelian terhadap merek atau produk tersebut akan semakin besar. Dengan mengenal produk tersebut, konsumen berharap bahwa produk yang dibelinya akan sesuai dengan harapan yang diinginkan. Pada saat ini konsumen lebih cenderung ingin mencoba hal-hal baru yang menurut pandangan mereka baik. Sebelum melakukan pembelian, konsumen memiliki banyak pertimbangan-pertimbangan dalam memilih suatu produk yang cocok dan sesuai dengan kebutuhan. Tahapan kecenderungan konsumen untuk bertindak sebelum keputusan membeli benar-benar dilaksanakan disebut dengan minat beli. Minat beli merupakan perilaku yang muncul sebagai respon terhadap suatu objek yang menunjukkan keinginan konsumen untuk melakukan pembelian (Kotler dan Keller, 2009:15). Minat beli akan menciptakan suatu motivasi yang terus terekam dalam benak konsumen dan akan timbul keinginan yang sangat kuat sehingga ketika konsumen ingin memenuhi kebutuhannya akan melakukan pembelian produk berdasarkan apa yang ada didalam benaknya. (Lee, Trail, Lee, \& Linda, 2000).

Berdasar pada hal tersebut perusahaan harus berupaya untuk menganalisis faktor-faktor yang mempengaruhi minat beli sehingga informasi yang tepat akan memberikan masukan yang tepat bagi perusahaan dalam menetukan strategi sebagai upaya peningkatan minat beli konsumen salah satunya adalah dengan cara meningkatkan bran awareness (Karam, 2015) (Bhakar, Bhakar, \& Dubey, 2015); (Lee et al., 2000). Di era generasi milenial kesadaran akan merek mengacu pada sejauh mana merek tinggal dalam benak konsumen. Sehingga GoFood dalam memngembangkan strategi marketingnya cenderung menggunakan platform sosial media sebagai wadah pemasaran dimana sosial media dengan tingkat pengguna paling dominan adalah generasi milenial, pemilihan focus pada generasi milenial didasarkan pada pemikiran bahwa kecenderungan perilaku konsumen itu sangat dipengaruhi oleh masa atau generasi dimana konsumen tersebut berada (Xiao \& Yang, 2019); (Sasmita \& Mohd Suki, 2015) . Dengan memperhatikan kecenderungan generasi milenial yang saat ini dihadapi oleh perusahaan maka salah satu platform media sosial yang menjadi sasaran GoFood untuk dilihat oleh konsumen khusunya generasi milenial adalah platform yang digunakan secara luas oleh generasi milenial seperti instagram dan youtube.

Saat ini hampir semua pelaku usaha telah memanfaatkan teknologi dalam pengembangan serta promosi bisnis yang dijalankannnya dan pemanfaatan tekhnologi tersebut yang paling banyak digunakan adalah pengembangan video advertising dan social media content pemanfaatan ini terbukti berpengaruh terhadap peningkatan minat beli konsumen. (Arshad dan Aslam, 2015), (Dewi dan Sulistyawati,2018)

(Maharani,2020) (Cangara, 2013).Pemanfaatan sosial media dengan baik akan mampu meningkatkan pengenalan produk kepada para konsumen yang pada akhinya berujung pada keputusan pembelian (POTURAK \& SOFTIĆ, 2019) hal senada juga diungkapkan oleh (Laksamana, 2018) yang juga menyatakan social media content berpengaruh terhadap minat beli konsumen.

Aplikasi berbagi video ini seperti diketahui sudah disematkan di hampir semua smartphone. Dilihat dari akun YouTube Gojek Indonesia, ada banyak video advertising yang ditempatkan di sana, mulai dari video advertising hingga video testimoni. Jika difilter menjadi video yang terpopuler, maka video advertising menjadi salah satu video yang paling banyak disaksikan, dengan jumlah penonton sebanyak 43 juta. Ini menjadi penting bagaimana GoFood membangun pola komunikasi pemasaran mereka lewat Youtube (Nur Azizah, dkk. 2020). Video advertising juga terbukti berpengaruh terhadap efektivitas pemasaran yang dilakukan oleh perusahaan (Jain, Rakesh, \& Chaturvedi, 2018);(Lai, Lai, \& Chiang, 2015);(Kroon, 2017). Penggunaan video advertising yang paling popular yang perlu diperhatikan oleh perusahaan 
yang akan menggunakan video adverstising dalam proosinya adalah youtube (Aziza \& Astuti, 2019)

Melalui pertimbangan yang telah diuraikan maka kerangka kospetual penelitian ini dapat digambarkan melalui gambar kerangka konsep penelitian sebagai berikut:

Gambar 2. Kerangka Konseptual Penelitian

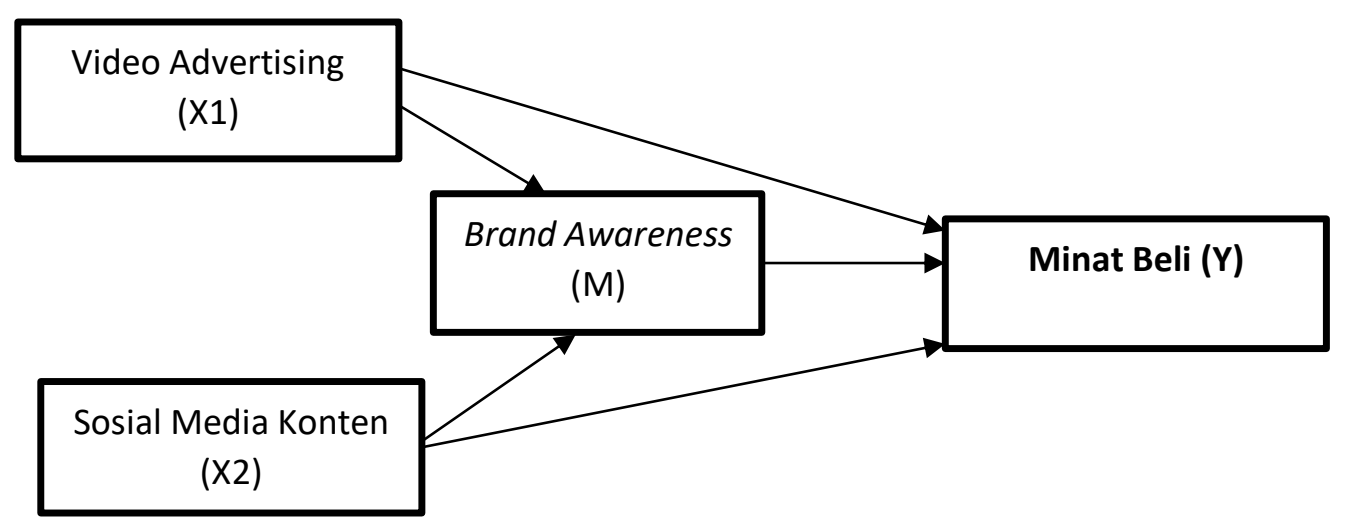

Berdasarkan kerangka konseptual, hipotesis penelitian sebagai berikut:

H1: Diduga bahwa video advertising berpengaruh positif dan signifikan terhadap minat beli pada aplikasi GoFood di Kota Makassar.

H2: Diduga bahwa sosial media konten berpengaruh positif dan signifikan terhadap minat beli pada aplikasi GoFood di Kota Makassar.

H3: Diduga bahwa video advertising melalui brand awareness berpengaruh positif dan signifikan terhadap minat beli pada aplikasi GoFood di Kota Makassar.

H4: Diduga bahwa sosial media konten melalui brand awareness berpengaruh positif dan signifikan terhadap minat beli pada aplikasi GoFood di Kota Makassar.

H5 : Diduga bahwa brand awareness berpengaruh positif dan signifikan terhadap minat beli pada aplikasi GoFood di Kota Makassar.

\section{METODE PENELITIAN}

Pendekatan yang digunakan dalam penelitian ini adalah pendekatan kuantitatif untuk menguji hipotesis dengan adanya hubungan antar variabel-variabel atau hubungan sebab akibat. Menurut (Sugiyono, 2017) mengemukakan bahwa Metode penelitian kuantitatif dapat diartikan sebagai metode penelitian yang berlandaskan pada filsafat positivism, digunakan untuk meneliti pada populasi atau sampel tertentu, pengumpulan data menggunakan instrument penelitian, analisis data bersifat kuantitatif/statistik, dengan tujuan untuk menguji hipotesis yang telah ditetapkan.

Penelitian kuantitatif merupakan jenis penelitian yang dapat dicapai atau diperoleh dengan menggunakan prosedur statistik atau cara lain dari kuantifikasi atau pengukuran. Penelitian ini mengkaji pengaruh video advertising dan sosial media konten melalui brand awareness terhadap minat beli pada aplikasi GoFood di Kota Makassar yang datanya dikumpulkan dengan penelitian berupa angka-angka skor pada kuesioner.

\section{HASIL DAN PEMBAHASAN \\ Outer Model}

Hasil pengujian Nilai Loading Factor dapat dilihat pada tabel berikut:

Tabel 1. Nilai Loading Factor

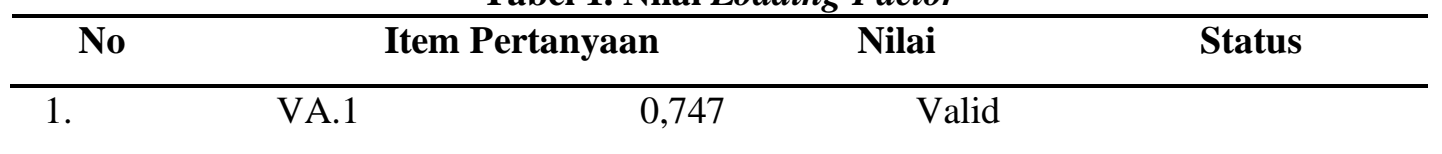




\begin{tabular}{llrl}
2. & \multicolumn{2}{c}{0,772} & \multicolumn{2}{c}{ Valid } \\
3. & VA.3 & 0,724 & \multicolumn{2}{c}{ Valid } \\
4. & VA.4 & 0,638 & Valid \\
5. & VA.5 & 0,781 & Valid \\
6. & VA.6 & 0,784 & Valid \\
7. & SMK.1 & 0,648 & Valid \\
8. & SMK.2 & 0,842 & Valid \\
9. & SMK.3 & 0,876 & Valid \\
10. & SMK.4 & 0,667 & Valid \\
11. & BA.1 & 0,553 & Valid \\
12. & BA.2 & 0,578 & Valid \\
13. & BA.3 & 0,794 & Valid \\
14. & BA.4 & 0,842 & Valid \\
15. & BA.5 & 0,743 & Valid \\
16. & MB.1 & 0,742 & Valid \\
17. & MB.2 & 0,804 & Valid \\
18. & MB.3 & 0,752 & Valid \\
19. & MB.4 & 0,754 & Valid \\
\hline
\end{tabular}

Sumber : Data diolah peneliti menggunakan Smart PLS.

Berdasarkan data dari tabel diatas dapat dijelaskan bahwa sebagian besar item pertanyaan bernilai > 0,50 atau dinyatakan valid.

Tabel 2. Nilai Construct Reliability and Validity

\begin{tabular}{lllll}
\hline Variabel & Cronbach's & rho_A & Composite & Average \\
Alpa & & Reliability & Variance \\
& Extracted
\end{tabular}

(AVE)

\begin{tabular}{lccccc}
\hline Brand Awareness & 0,755 & 0,785 & 0,833 & 0,506 \\
Minat Beli & 0,761 & 0,762 & 0,848 & 0,583 \\
Sosial Media Konten & 0,756 & 0,775 & 0,847 & \multicolumn{2}{c}{0,585} \\
Video Advertising & 0,838 & 0,850 & 0,880 & 0,552 \\
\hline
\end{tabular}

Sumber : Data diolah peneliti menggunakan Smart PLS

Berdasarkan tabel diatas terlihat bahwa nilai Average Variance Extracted (AVE) untuk semua variabel berada pada nilai $>0,5$ dan dinyatakan valid. Serta nilai loading factor $>0,5$. Sehingga dapat dijelaskan bahwa semua item pertanyaan dalam kuesioner sudah memenuhi persyaratan validitas.

a. Discriminant Validity adalah model pengukuran dengan refleksif indikator dinilai berdasarkan cross loading pengukuran dengan konstruk. Jika korelasi konstruk dengan item pengukuran lebih besar daripada ukuran konstruk lainnya, maka menunjukkan ukuran blok mereka lebih baik dibandingkan dengan blok lainnya. Sedangkan menurut metode lain untuk menilai discriminant validity yaitu dengan membandingkan nilai squareroot of average extracted (AVE). Dari hasil kalkulasi data yang dilakukan pada Smart PLS maka diperoleh data sebagai berikut :

Tabel 3. Nilai Discriminant Validity

\begin{tabular}{lllc}
\hline Brand & Minat Beli & $\begin{array}{l}\text { Sosial Media } \\
\text { Konten }\end{array}$ & $\begin{array}{c}\text { Video } \\
\text { Advertising }\end{array}$ \\
\hline
\end{tabular}


Brand Awareness

Minat Beli

Sosial Media Konten $\quad 0,733$

Video Advertising $\quad 0,655$
0,712

Sumber : Data diolah peneliti menggunakan Smart PLS

0,764
0,662

Pada tabel diatas merupakan nilai cross loading factor yang berguna untuk mengetahui apakah konstruk memiliki diskriminan yang memadai yaitu dengan cara membandingkan nilai loading pada konstruk yang dituju harus lebih besar dibandingkan dengan nilai loading dengan konstruk yang lain.

b. Composite Reliability adalah indikator untuk mengukur suatu konstruk yang dapat dilihat pada view latent variable coefficients. Untuk mengevaluasi composite reliability terdapat dua alat ukur yakni internal consistency dan cronbach's alpha. Didalam pengukuran tersebut apabila nilai yang dicapai adalah > 0,80 maka dapat dikatakan bahwa konstruk tersebut memiliki reliabilitas yang tinggi.

Tabel 4. Nilai Composite Reliability

\begin{tabular}{|c|c|c|c|c|}
\hline No & \multicolumn{3}{|c|}{$\begin{array}{l}\text { Composite } \\
\text { Reliability }\end{array}$} & Status \\
\hline 1. & Brand Awareness & 0,833 & & \\
\hline 2. & Minat Beli & 0,848 & Reliabe & \\
\hline 3. & Sosial Media Konten & 0,847 & & \\
\hline 4. & Video Advertising & 0,880 & & \\
\hline
\end{tabular}

Sumber : Data diolah peneliti menggunakan Smart PLS

Berdasarkan data diatas terlihat bahwa semua variabel terbukti reliabel dengan nilai composite reliability $>0,70$. Adapun nilai composite reliability terendah adalah 0,833 pada variabel brand awareness dan nilai tertinggi adalah 0,880 pada variabel video advertising. Untuk nilai composite reliability $>0,8$ memiliki tingkat reliabilitas yang tinggi.

c. Average Variance Extracted (AVE) digunakan untuk mengukur reliabilitas kuesioner dengan batasan untuk reliabel adalah apabila nilai Average Variance Extracted (AVE) > 0,5 . Validitas konvergen mempunyai makna bahwa seperangkat indikator mewakili satu variabel laten dan yang mendasari variabel laten tersebut. Perwakilan tersebut dapat di demonstrasikan melalui unidimensionalitas yang dapat digambarkan dengan menggunakan nilai rata-rata varian yang diekstraksi (Average Variance Extracted / AVE). Dalam penelitian ini diperoleh data Average Variance Extracted (AVE) seperti pada tabel berikut ini :

Tabel 5. Nilai Average Varian Extracted

\begin{tabular}{|c|c|c|c|}
\hline No & Variabel & $\begin{array}{c}\text { Average Variance } \\
\text { Extracted }\end{array}$ & Status \\
\hline 1. & Brand Awareness & 0,506 & Valid \\
\hline 2. & Minat Beli & 0,583 & Valid \\
\hline 3. & Sosial Media Konten & 0,585 & Valid \\
\hline 4. & Video Advertising & 0,552 & Valid \\
\hline
\end{tabular}

Sumber : Data diolah peneliti menggunakan Smart PLS

Berdasarkan data diatas menunjukkan bahwa semua variabel memiliki nilai Average Variance Extracted (AVE) > 0,50 yang memiliki makna bahwa semua variabel dengan indikatornya dapat dikatakan valid dan reliabel. Adapun nilai yang diperoleh berdasarkan tabel 
olahan data PLS diatas dengan nilai Average Variance Extracted (AVE) terendah adalah 0,506 pada variabel brand awareness dan nilai Average variance Extracted (AVE) tertinggi adalah 0,585 pada variabel sosial media konten.

d. Cronbach's Alpha adalah uji reliabilitas yang dilakukan untuk memperkuat hasil dari composite reliability. Suatu variabel dikatakan reliabel jika memiliki nilai cronbach's alpha $>0,7$.

Tabel 6. Nilai Cronbach's Alpha

\begin{tabular}{|c|c|c|c|c|}
\hline Variabel & $\begin{array}{c}\text { Cronbach's } \\
\text { Alpha }\end{array}$ & & $\begin{array}{l}\text { Composite } \\
\text { Reliability }\end{array}$ & Status \\
\hline 1. Brand Awareness & 0,755 & & 0,833 & Reliabel \\
\hline 2. Minat Beli & 0,761 & 0,848 & Reliabel & \\
\hline Sosial Media Konten & $\mathrm{n} \quad 0,756$ & & 0,847 & bel \\
\hline 4. Video Advertising & 0,838 & & 0,880 & bel \\
\hline
\end{tabular}

Sumber : Data diolah peneliti menggunakan Smart PLS

Berdasarkan data pada tabel diatas hasil dari kalkulasi Smart PLS maka diperoleh nilai cronbach's alpha untuk semua item variabel dengan nilai cronbach's alpha $>0,5$ sehingga dapat dikatakan bahwa kuesioner yang digunakan sudah reliabel. Adapun nilai cronbach's alpha terendah adalah 0,755 pada variabel brand awareness sedangkan untuk nilai cronbach's alpha tertinggi adalah 0,838 pada variabel video advertising.

Uji yang dilakukan diatas merupakan uji pada outer model untuk indikator reflektif. Sedangkan untuk indikator formatif dilakukan pengujian yang berbeda yaitu dengan menggunakan uji multicollinearity. Uji ini dilakukan untuk mengetahui hubungan antar indikator. Untuk mengetahui apakah indikator formatif mengalami multicollinearity dengan mengetahui nilai VIF. Nilai VIF berkisar antara 5-10 dapat dikatakan bahwa indikator tersebut terjadi multicollinearity. Dalam penelitian ini nilai VIF yang dijadikan ukuran adalah nilai VIF $<5$.

Tabel 7. Nilai Collinearity Statistic (VIF)

\begin{tabular}{|c|c|c|c|c|}
\hline No & Item Pertanyaan & Nilai VIF & & Status \\
\hline 1 & VA.1 & 1,774 & Valid & \\
\hline 2 & VA. 2 & 1,695 & Valid & \\
\hline 3 & VA.3 & 1,628 & Valid & \\
\hline 4 & VA.4 & 1,501 & Valid & \\
\hline 5 & VA. 5 & 1,775 & Valid & \\
\hline 6 & VA.6 & 1,849 & Valid & \\
\hline 7 & SMK.1 & 1,191 & & Valid \\
\hline 8 & SMK.2 & 2,514 & & Valid \\
\hline 9 & SMK.3 & 2,754 & & Valid \\
\hline 10 & SMK.4 & 1,330 & & Valid \\
\hline 11 & BA.1 & 1,722 & Valid & \\
\hline 12 & BA.2 & 1,870 & Valid & \\
\hline 13 & BA. 3 & 1,733 & Valid & \\
\hline 14 & BA. 4 & 2,436 & Valid & \\
\hline 15 & BA. 5 & 1,997 & Valid & \\
\hline 16 & MB.1 & 1,448 & Valid & \\
\hline 17 & MB.2 & 1,692 & Valid & \\
\hline 18 & MB.3 & 1,449 & Valid & \\
\hline 17 & MB.4 & 1,493 & Valid & \\
\hline
\end{tabular}


Sumber : Data diolah peneliti menggunakan Smart PLS

Berdasarkan data pada tabel diatas terlihat bahwa nilai collinearity (VIF) yang diperoleh dari pengolahan data menggunakan Smart PLS menunjukkan bahwa semua item pertanyaan memiliki nilai VIF $<5$. Dimana nilai VIF $<5$ dinyatakan terbebas dari multikolinearitas. Adapun nilai VIF terendah sebesar 1,191 dan nilai tertinggi sebesar 1,997.

\section{Inner Model}

Uji pada model struktural dilakukan untuk menguji hubungan antara konstruk laten diantaranya dengan uji R-Square. Nilai R-Square merupakan koefisien determinasi pada konstruk endogen. R-Square digunakan untuk mengukur tingkat variansi perubahan variabel independen terhadap variabel dependen. Menurut Chin (1998), jika nilai R-Square sebesar 0,67 dinyatakan kuat, 0,33 dinyatakan moderat dan 0,19 dinyatakan lemah. Berikut ini adalah hasil nilai R-Square yang digunakan untuk mengukur tingkat variansi perubahan :

Tabel 8. Nilai R-Square

\begin{tabular}{lcc}
\hline No & Variabel & R-Square \\
\hline 1. & Brand Awareness & 0,605 \\
2. & Minat Beli & 0,581 \\
\hline \multicolumn{2}{l}{ Sumber $:$ Data diolah peneliti menggunakan Smart $P L S$} &
\end{tabular}

Berdasarakan data pada tabel diatas dapat diketahui bahwa nilai $\mathrm{R}$-Square pada variabel brand awareness sebesar 0,605. Artinya variabel brand awareness dapat dijelaskan oleh variabel video advertising dan variabel sosial media konten sebesar $60,5 \%$, sedangkan sisanya sebesar 39,5\% dijelaskan oleh variabel lain diluar dari model penelitian ini.

Nilai R-Square pada variabel minat beli sebesar 0,581. Artinya variabel minat beli dapat dijelaskan oleh variabel video advertising, sosial media konten dan brand awareness sebesar $58,1 \%$, sedangkan sisanya sebesar $41,9 \%$ dijelaskan oleh variabel lain diluar dari model penelitian ini. Untuk penilaian goodness of fit juga dapat diketahui melalui nilai dari nilai QSquare. Nilai Q-Square memiliki arti yang sama dengan nilai coefficient determination (RSquare) pada analisis regresi, dimana semakin tinggi nilai dari Q-Square, maka model tersebut dapat dikatakan semakin baik atau semakin fit dengan data. Untuk menentukan nilai dari QSquare dapat diselesaikan dengan menggunakan persamaan sebagai berikut :

$$
\begin{aligned}
& \mathrm{Q} \text {-Square }=1\left[\left(1-\mathrm{R}^{2} 1\right)\left(1-\mathrm{R}^{2} 2\right)\right] \\
& \text { Dimana: } \mathrm{R}^{2} 1 \text { = Nilai R-Square Brand Awareness } \\
& \mathrm{R}^{2} 2=\text { Nilai R-Square Minat Beli } \\
& \text { Sehingga diperoleh nilai perhitungan: } \\
& \mathrm{Q}-\text { Square }=1-\left[\left(1-\mathrm{R}^{2} 1\right) \times\left(1-\mathrm{R}^{2} 2\right)\right] \\
& =1-[(1-0,605) \times(1-0,581)] \\
& =1-(0,395 \times 0,419) \\
& =1-0,165 \\
& =0,835
\end{aligned}
$$

Berdasarkan dari hasil perhitungan persamaan diatas, diperoleh nila Q-Square sebesar 0,835. Hal tersebut menunjukkan bahwa besarnya keragaman dari data penelitian yang dijelaskan oleh model penelitian adalah sebesar 83,5\%. Sedangkan untuk sisanya sebesar 16,5\% dijelaskan oleh faktor lain yang berada diluar dari model penelitian ini. Dengan demikian dapat dijelaskan bahwa model penelitian ini dinyatakan telah memiliki goodness of fit yang baik. 


\section{PENGUJIAN HIPOTESIS}

Untuk mengetahui hubungan antar variabel laten dalam model penelitian ini dapat dilihat dari hasil estimasi koefisien jalur atau path coefficients dan tingkat signifikansinya atau $\mathrm{P}$ Values. Untuk menguji hipotesis pada penelitian yang diajukan, dapat dilihat dari besarnya nilai $\mathrm{P}$ Value. Apabila nilai P Value $<0,05$ maka Ho ditolak dan Ha diterima atau berpengaruh secara signifikan yang dikorelasikan dengan nilai t-statistik, dimana nilai t-statistik > t-tabel. Nilai tstatistik adalah hasil estimasi path coefficients untuk menguji kekuatan pengaruh antar variabel dan menjelaskan ketegasan hubungan antar arah variabel. Adapun penjelasannya dapat dilihat pada tabel berikut :

Tabel 9. Hasil Path Coefficients

\begin{tabular}{|c|c|c|c|c|c|}
\hline & $\begin{array}{l}\text { Original } \\
\text { Sample } \\
\text { (O) }\end{array}$ & $\begin{array}{l}\text { Sample } \\
\text { Mean } \\
\text { (M) }\end{array}$ & $\begin{array}{l}\text { Standard } \\
\text { Deviation } \\
\text { (STDEV) }\end{array}$ & $\begin{array}{c}\text { T-Statistics } \\
\text { (|O/STDEV|) }\end{array}$ & P Value \\
\hline $\begin{array}{l}\text { Video Advertising -> } \\
\text { Minat Beli }\end{array}$ & 0,191 & 0,190 & 0,084 & 2,282 & $\overline{0}, 023$ \\
\hline $\begin{array}{l}\text { Sosial Media Konten -> } \\
\text { Minat Beli }\end{array}$ & 0,230 & 0,197 & 0,133 & 1,725 & 0,085 \\
\hline $\begin{array}{l}\text { Video Advertising -> } \\
\text { Brand Awareness }\end{array}$ & 0,330 & 0,330 & 0,101 & 3,279 & 0,001 \\
\hline $\begin{array}{l}\text { Sosial Media Konten -> } \\
0,000\end{array}$ & 0,531 & 0,541 & 0,120 & 4,430 & \\
\hline $\begin{array}{l}\text { Brand Awareness } \\
\text { Brand Awareness -> } \\
\text { Minat Beli }\end{array}$ & 0,431 & 0,470 & 0,129 & 3,340 & 0,001 \\
\hline
\end{tabular}

Sumber : Data diolah peneliti menggunakan Smart PLS

Nilai t-tabel adalah 1,985 diperoleh dari data $t$ tabel. Berdasarkan penjelasan pada tabel estimasi path coefficient diatas yang mencantumkan nilai P Value maka dapat dijelaskan dengan hipotesis sebagai berikut :

a. Uji Hipotesis 1 (Video Advertising terhadap Minat Beli)

Video advertising berpengaruh positif dan signifikan terhadap minat beli pada aplikasi GoFood di Kota Makassar. Dasar pengambilan keputusannya adalah sebagai berikut :

Ho = Video advertising tidak berpengaruh terhadap minat beli, dan

$\mathrm{Ha}=$ Video advertising berpengaruh terhadap minat beli.

Dengan persyaratan apabila nilai dari :

$\mathrm{P}$ Value > 0,05 maka Ho diterima dan Ha ditolak, apabila

$\mathrm{P}$ Value < 0,05 maka Ho ditolak dan Ha diterima.

Adapun penjelasan dari hasil pengujian yang diperoleh berdasarkan tabel path coefficient memberikan nilai $\mathrm{P}$ Value sebesar 0,023 sehingga nilai $\mathrm{P}$ Value $<0,05$ yang tergolong sebagai kategori signifikan dengan nilai t statistics sebesar 2,282 >t tabel, dengan pengaruh sebesar 0,191 dengan kata lain Ho ditolak dan Ha diterima. Hal tersebut memberikan makna bahwa video advertising berpengaruh positif dan signifikan terhadap minat beli pada aplikasi GoFood di Kota Makassar, artinya video advertising yang ditampilkan oleh GoFood sangat menarik dan informatif sehingga tumbuh niat untuk melakukan pembelian.

\section{b. Uji Hipotesis 2 (Sosial Media Konten terhadap Minat Beli)}

Sosial media konten berpengaruh positif namun tidak signifikan terhadap minat beli pada aplikasi GoFood di Kota Makassar. Dasar pengambilan keputusannya adalah sebagai berikut :

Ho $=$ Sosial media konten berpengaruh terhadap minat beli, dan 
$\mathrm{Ha}=$ Sosial media konten tidak berpengaruh terhadap minat beli.

Dengan persyaratan apabila nilai dari :

$\mathrm{P}$ Value $>0,05$ maka Ho diterima dan Ha ditolak, apabila

$\mathrm{P}$ Value $<0,05$ maka Ha diterima dan Ho ditolak.

Adapun penjelasan dari hasil pengujian yang diperoleh berdasarkan tabel path coefficient memberikan nilai $\mathrm{P}$ Value sebesar 0,085 sehingga nilai $\mathrm{P}$ Value $>0,05$ yang tergolong sebagai kategori tidak signifikan dengan nilai t statistics sebesar $1,725<\mathrm{t}$ tabel, dengan pengaruh sebesar 0,230 dengan kata lain Ho diterima dan Ha ditolak. Hal tersebut memberikan makna bahwa sosial media konten berpengaruh positif namun tidak signifikan terhadap minat beli pada aplikasi GoFood di Kota Makassar, artinya konten-konten yang ditampilkan oleh GoFood di sosial media tidak menarik minat konsumen secara langsung untuk melakukan pembelian atau menggunakan layanan dari GoFood.

c. Uji Hipotesis 3 (Video Advertising melalui Brand Awareness terhadap Minat Beli) atau Uji Hipotesis dengan efek mediasi.

Video advertising melalui brand awareness berpengaruh positif dan signifikan terhadap minat beli pada aplikasi GoFood di Kota Makassar. Dasar pengambilan keputusannya adalah sebagai berikut :

Ho = Video advertising melalui brand awareness tidak berpengaruh terhadap minat beli, dan

$\mathrm{Ha}=$ Video advertising melalui brand awareness berpengaruh terhadap minat beli.

Dengan persyaratan apabila nilai dari :

P Value $>0,05$ maka Ho diterima dan Ha ditolak, apabila

$\mathrm{P}$ Value $<0,05$ maka Ho ditolak dan Ha diterima.

- Jika koefisien jalur atau path coefficient antara video advertising dan minat beli dari dirrect effect ke indirect effect tidak berubah dan tetap signifikan, maka Ho diterima dan Ha ditolak.

- Jika koefisien jalur atau path coefficient antara video advertising dan minat beli dari direct effect ke indirect effect nilainya turun dan tetap signifikan maka, Ho ditolak dan Ha diterima dengan mediasi sebagian atau partial mediation.

- Jika koefisien jalur atau path coefficient antara video advertising dan minat beli dari direct effect ke indirect effect nilainya turun dan menjadi tidak signifikan, maka Ho ditolak dan Ha diterima dengan mediasi penuh atau full mediation.

Berikut ini adalah data untuk nilai dari path coefficient dan nilai specific indirect effects yang dijadikan sebagai dasar acuan untuk melihat perubahan nilai dari masing-masing variabel pengujian hipotesis adalah :

Tabel 10. Nilai Path Coefficient

\begin{tabular}{|c|c|c|c|c|c|c|c|}
\hline No & Hipotesis & $\begin{array}{l}\text { Original } \\
\text { Sample } \\
(\mathbf{O})\end{array}$ & $\begin{array}{l}\text { Sample } \\
\text { Mean } \\
(\mathrm{M})\end{array}$ & $\begin{array}{l}\text { Standard } \\
\text { Deviation } \\
\text { (STDEV) }\end{array}$ & $\begin{array}{l}\text { T Statistics } \\
(|\mathrm{O} / \mathrm{STDEV}|)\end{array}$ & P Value & \\
\hline $\begin{array}{l}1 \\
0,02\end{array}$ & Video Advertising & & 0,191 & 0,190 & 0,084 & & 2,282 \\
\hline $\begin{array}{l}2 \\
0,08\end{array}$ & \multicolumn{2}{|c|}{$\begin{array}{l}\text { Sosial Media Konten } \\
55\end{array}$} & 0,230 & 0,197 & 0,133 & & 1,725 \\
\hline
\end{tabular}


Sumber : Data diolah peneliti menggunakan Smart PLS

Tabel 11. Nilai Specific Indirect Effects

\begin{tabular}{|c|c|c|c|c|c|c|}
\hline No & Hipotesis & $\begin{array}{l}\text { Original } \\
\text { Sample } \\
(\text { O) }\end{array}$ & $\begin{array}{c}\text { Sample } \\
\text { Mean } \\
\text { (M) }\end{array}$ & $\begin{array}{l}\text { Standard } \\
\text { Deviation } \\
\text { (STDEV) }\end{array}$ & $\begin{array}{c}\text { T Statistics } \\
\text { (|O/STDEV|) }\end{array}$ & P Value \\
\hline 1 & $\begin{array}{l}\text { Video Advertising } \\
\text {->Brand Awareness } \\
\text {->Minat Beli }\end{array}$ & 0,142 & 0,155 & 0,062 & 2,277 & \\
\hline 2 & $\begin{array}{l}\text { Sosial Media Konten } \\
->\text { Brand Awareness } \\
->\text { Minat Beli }\end{array}$ & 0,229 & 0,256 & 0,097 & 2,368 & \\
\hline
\end{tabular}

Sumber : Data diolah peneliti menggunakan Smart PLS

Berdasarkan dari data tabel yang dijelaskan diatas diperoleh nilai path coefficients antara video advertising dan minat beli dari 0,191 turun menjadi 0,142 pada specific indirect effects serta hubungan dari video advertising melalui brand awareness terhadap minat beli tetap signifikan, maka Ho ditolak dan Ha diterima dengan mediasi sebagian atau partial mediation. Hasil ini memberikan makna bahwa brand awareness memediasi pengaruh video advertising terhadap minat beli dengan mediasi sebagian. Artinya video advertising dapat berpengaruh secara langsung dan tidak langsung terhadap minat beli. Selain video advertising, brand awareness juga berperan penting terhadap minat beli sebagai mediasi pengaruh video advertising terhadap minat beli, yang berarti untuk meningkatkan minat beli penggunanya terlebih dulu GoFood membangun brand awareness yang tinggi sehingga dikenal sebagai layanan pesan antar makanan online yang menarik.

d. Uji Hipotesis 4 (Sosial Media Konten melalui Brand Awareness terhadap minat beli) atau Uji Hipotesis dengan efek mediasi.

Sosial media konten berpengaruh positif dan signifikan melalui brand awareness terhadap minat beli pada aplikasi GoFood di Kota Makassar. Dasar pengambilan keputusannya adalah sebagai berikut :

Ho $=$ Sosial media konten melalui brand awareness tidak berpengaruh terhadap minat beli, dan

$\mathrm{Ha}=$ Sosial media konten melalui brand awareness berpengaruh terhadap minat beli.

Dengan persyaratan apabila nilai dari :

P Value $>0,05$ maka Ho diterima dan Ha ditolak, apabila

$\mathrm{P}$ Value $<0,05$ maka Ho ditolak dan Ha diterima.

- Jika koefisien jalur atau path coefficient antara sosial media konten dan minat beli dari direct effect ke indirect effect tidak berubah dan tetap signifikan, maka Ho diterima dan Ha ditolak.

- Jika koefisien jalur atau path coefficient antara sosial media konten dan minat beli dari direct effect ke indirect effect nilainya turun dan tetap signifikan, maka Ho ditolak dan Ha diterima dengan mediasi sebagian atau partial mediation.

- Jika koefisien jalur atau path coefficient antara sosial media konten dan minat beli dari direct effect ke indirect effect nilainya turun dan menjadi tidak signifikan, maka Ho ditolak dan Ha diterima dengan mediasi penuh atau full mediation.

Dari hasil pengujian menunjukkan nilai path coefficient antara sosial media konten dan minat beli adalah 0,230 kemudian jika pengaruh social media content terhadap minat 
membeli dimediasi dengan menggunakan variabel brand awareness maka nilai pengaruhnya menjadi turun dan menghasilkan nilai sebesar 0,229 dengan menggunakan variabel mediasi, pengaruh sosial media konten melalui brand awareness terhadap minat beli tetap signifikan, dari hasil ini maka Ho ditolak dan Ha diterima dengan mediasi sebagian atau partial mediation. Hasil ini memberikan makna bahwa brand awareness memediasi pengaruh sosial media konten terhadap minat beli dengan mediasi sebagian. Artinya brand awareness juga berperan penting terhadap minat beli sebagai mediasi pengaruh sosial media konten terhadap minat beli, yang berarti untuk meningkatkan minat beli pengguna GoFood maka salah satu cerminan dari upaya untuk meningkatkan minat tersebut adalah membangun brand awareness yang tinggi, sehingga dalam proses pengiklanan di sosial media maka perlu juga untuk memperhatikan konten-konten yang digunakan.

\section{e. Uji Hipotesis 5 (Brand Awareness terhadap Minat Beli)}

Brand awareness berpengaruh positif dan signifikan terhadap minat beli pada aplikasi GoFood di Kota Makassar.Jika dasar pengambilan keputusannya adalah :

Ho $=$ Brand awareness tidak berpengaruh terhadap minat beli, dan

$\mathrm{Ha}=$ Brand awareness berpengaruh terhadap terhadap minat beli.

Dengan persyaratan apabila nilai dari :

P Value $>0,05$ maka Ho diterima dan Ha ditolak, dan apabila

$\mathrm{P}$ Value $<0,05$ maka Ho ditolak dan Ha diterima.

Dari hasil pengujian yang diperoleh berdasarkan tabel path coefficient memberikan nilai $\mathrm{P}$ Value sebesar 0,001 sehingga nilai $\mathrm{P}$ Value $<0,05$ yang tergolong sebagai kategori signifikan dengan nilai $\mathrm{t}$ statistics sebesar 3,340 > t tabel, dengan pengaruh sebesar 0,431 dengan kata lain Ho ditolak dan Ha diterima. Hal tersebut memberikan makna bahwa brand awareness berpengaruh positif dan signifikan terhadap minat beli pada aplikasi GoFood di Kota Makassar, artinya brand awareness yang tinggi mampu menarik minat konsumen untuk menggunakan layanan dari GoFood karena brand GoFood sebenarnya sudah sangat kuat sebagai pioneer dari layanan pesan antar makanan online di Indonesia.

\section{KESIMPULAN}

Penelitian ini menyimpulkan bahwa brand awareness memediasi atau mengintervening pengaruh video advertising dan sosial media konten terhadap minat beli. Sedangkan sosial media konten tidak mampu mempengaruhi secara langsung terhadap minat beli. Jadi, dapat diartikan bahwa untuk meningkatkan minat beli pada pengguna aplikasi GoFood di Kota Makassar maka salah satu cerminan dari upaya untuk meningkatkan minat tersebut adalah memiliki brand awareness yang kuat dibenak konsumen. Sehingga dalam proses pengiklanan di sosial media maka perlu juga memperhatikan konten-konten yang digunakan agar penyampaian pesan dalam iklan tersebut menarik dan informatif. Layaknya sebuah brand yang sudah kuat sebenarnya Gojek sebagai pioneer telah memiliki brand yang sangat kuat hampir semua orang yang menggunakan jasa layanan pesan antar selalu berfikir tentang Gojek. Namun demikian, dengan adanya perkembangan dengan munculnya berbagai macam layanan serupa seperti Grab dan Maxim yang juga sudah mulai dikenal membuat brand image menjadi pertaruhan bagi perusahaan jasa online dalam melakukan persaingan bisnis. Maka permasalahan brand image juga menjadi suatu hal yang sangat menarik untuk dianalisis melalui sebuah penelitian.

\section{DAFTAR PUSTAKA}

Akhtar, N., Ashraf, A., \& Latif, M. (2016). Impact of a Brand Equity on Consumer Purchase

Decision in L'Oreal Skincare Products. International Review of Management and Business Research, 5(3), 2306-9007.

Aziza, D. N., \& Astuti, R. D. (2019). Evaluating The Effect of YouTube Advertising towards 
Young Customers' Purchase Intention. 72(December 2017), 93-98.

https://doi.org/10.2991/icbmr-18.2019.16

Bal, H. Ç., \& Erkan, Ç. (2019). ScienceDirect ScienceDirect ScienceDirect Industry 4 . 0 and Competitiveness Industry 4.0 and Competitiveness. 00. https://doi.org/10.1016/j.procs.2019.09.096

Bhakar, S., Bhakar, S., \& Dubey, A. (2015). Analysis of the Factors Affecting Customers ' Purchase Intention: The Analysis * of * the * Factors * Affecting * Customers '* Purchase *Intention :* The * Mediating * Role * of * Customer * Knowledge * and * Perceived *Value *. (January). https://doi.org/10.14738/assrj.21.139

Chi, H. K. (2009). The Impact of Brand Awareness on Consumer Purchase Intention: The Mediating Effect of Perceived Quality and Brand Loyalty. The Journal of International Management Studies, 4(1), 135-144.

Gusti Noorlitaria, A., Pangestu, F. R., Fitriansyah, Surapati, U., \& Mahsyar, S. (2020). How does brand awareness affect purchase intention in mediation by perceived quality and brand loyalty? Journal of Critical Reviews, 7(2), 103-109. https://doi.org/10.31838/jcr.07.02.20

Huang, R., \& Sarigöllü, E. (2012). How brand awareness relates to market outcome, brand equity, and the marketing mix. Journal of Business Research, 65(1), 92-99. https://doi.org/10.1016/j.jbusres.2011.02.003

Jain, G., Rakesh, S., \& Chaturvedi, K. R. (2018). Online video advertisements' effect on purchase intention: An exploratory study on youth. International Journal of E-Business Research, 14(2), 87-101. https://doi.org/10.4018/JJEBR.2018040106

Karam, A. A. (2015). An Analysis Study of Improving Brand Awareness and Its Impact on Consumer Behavior Via Media in North Cyprus (A Case Study of Fast Food Restaurants) The impact of customer service in eco-tourism area to Kurdistan income with special reference to Duhok Cit. 6(1), 66-80. Retrieved from www.ijbssnet.com

Kroon, M. De. (2017). Online video advertising : how message tone and length persuade the audience.1-58. Retrieved from https://essay.utwente.nl/72909/1/DeKroon_MA_BMS.pdf

Lai, Y., Lai, C., \& Chiang, H. (2015). Exploring the effects of online video advertising message display, product placement, and product involvement on advertising effectiveness. International Journal of Economics and Statistics, 3, 117-127.

Laksamana, P. (2018). International Review of Management and Marketing Impact of Social Media Marketing on Purchase Intention and Brand Loyalty: Evidence from Indonesia's Banking Industry. International Review of Management and Marketing, 8(1), 13-18. Retrieved from http:www.econjournals.com

Lee, D., Trail, G. T., Lee, C., \& Linda, J. (2000). Exploring Factors that Affect Purchase Intention of Athletic Team Merchandise. (1995).

Maria, E., Economiche, S., Fanno, M., Maria, E. Di, Economiche, S., \& Fanno, M. (2017). THE STRATEGIC ROLE. (November), 0-6.

Meadows-Klue, D. (2008). Mobile Marketing: Achieving Competitive Advantage Through Wireless Technology. Journal of Direct, Data and Digital Marketing Practice, Vol. 9, pp. 406-408. https://doi.org/10.1057/palgrave.dddmp.4350102

POTURAK, M., \& SOFTIĆ, S. (2019). Influence of Social Media Content on Consumer Purchase Intention: Mediation Effect of Brand Equity. Eurasian Journal of Business and Economics, 12(23), 17-43. https://doi.org/10.17015/ejbe.2019.023.02

Sasmita, J., \& Mohd Suki, N. (2015). Young consumers' insights on brand equity: Effects of brand association, brand loyalty, brand awareness, and brand image. International Journal of Retail and Distribution Management, 43(3), 276-292. https://doi.org/10.1108/IJRDM02-2014-0024

Shahid, Z., Hussain, T., \& Zafar, F. (2017). The Impact of Brand Awareness on the Consumers' Purchase Intention. Journal of Accounting \& Marketing, 06(01), 34-38. 
https://doi.org/10.4172/2168-9601.1000223

Smuts, S., \& Merwe, A. Van Der. (2020). A Strategic Organisational Perspective of Industry 4. 0 : A Conceptual Model. https://doi.org/10.1007/978-3-030-44999-5

Xiao, A., \& Yang, S. (2019). administrative sciences Factors Affecting Purchase Intentions in Generation Y: An Empirical Evidence from Fast Food Industry in Malaysia. (2011). https://doi.org/10.3390/admsci9010004 